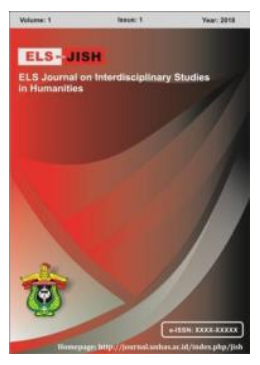

ELS-JISH

ELS Journal on Interdisciplinary Studies on Humanities

Volume 3 Issue 4, 2020

ISSN (print) : 2621-0843

ISSN (online) : 2621-0835

Homepage : http://journal.unhas.ac.id/index.php/jish

\title{
Extensive Reading on Wattpad and Its Benefits to Students' English Skills: Students' Perceptions
}

\author{
Intan Permatasari ${ }^{1}$, Agus Wijayanto ${ }^{2}$, Diah Kristina ${ }^{3}$ \\ 1 ipermatasari5794@gmail.com
}

\begin{abstract}
The purpose of this study was to explore students' perception's towards Extensive Reading on Wattpad platform as well as its benefits to students' English skills. Extensive Reading enables students to read a great deal amount of reading materials based on their personal interests and level of comprehension which is actually applied outside the class room for most people consider it as reading for pleasure. It has also been known that Extensive Reading has many benefits in improving students' language skills. The advancement of technology over the years allows people to do many activities online, including Extensive Reading activity. Thus, Wattpad is considered to have enormous and various reading materials that can support extensive reading for the students. This study is a case study. The data were obtained from an in-depth interview with the participant who were two undergraduate students majoring English Education from a state university in Indonesia. The participants were selected purposively for the reason they were known to have been doing extensive reading activity on Wattpad for a quite long time, specifically for more than three years. The research findings showed that students have positive perceptions towards Extensive Reading on Wattpad which are categorized into three elements namely cognitive, affective, and conative. Four notable benefits of Extensive Reading on Wattpad were also mentioned by the students such as it contributed in unconsciously improving students' writing skills, vocabulary mastery, speaking skills, as well as listening skills.
\end{abstract}

Keywords: Extensive Reading, Wattpad, Students' Perceptions, English Skills

How to cite: Permatasari, I., Wijayanto, A. \& Kristina, D. (2020). Extensive Reading on Wattpad and Its Benefits to Students' English Skills: Students' Perceptions. ELS Journal on Interdisciplinary Studies in Humanities, 3(4), 518-530. DOI:

https://doi.org/10.34050/elsjish.v3i4.11714

\section{Introduction}

Reading is one of the most crucial skills in educational settings (Grabe, 2009). It takes students a good reading ability to discover the content of the text. Moreover, (Harrison, 2004) states that the importance of reading is not only related to the development of knowledge but also to the thinking capability of the people. This capability will therefore be the basic development of emotional, moral and verbal intelligence. Additionally, these developments establish what kind of person that person will be. Reading cannot be separated from the learning process since it is a crucial matter and a necessity as a tool of

\footnotetext{
${ }^{1,3}$ Sebelas Maret University, Indonesia

${ }^{2}$ Muhammadiyah University of Surakarta, Indonesia
} 
education (Mokhtari et al., 2009). Reading also provides benefits to the students in terms of improving their reading comprehension, writing skill, vocabulary knowledge, and spelling skill (Mason \& Krashen, 1997). Moreover, reading is not only cognitive processes but also psychological processes of thinking and learning. From this view, reading is a complex mental process which has various interaction such as information-processing of thinking and learning (Hacker, 2009).

In Indonesia, however, it has been known that people lack of reading interests, including students (Rahman, 2018). Consequently, it could detain their learning process and understanding of the material, especially in lessons which involve reading. (Cain et al., 2004) state that bad readers are poor in making inferences and find difficulties in understanding the text. Besides, the (Andreas, 2018) found out that Indonesian EFL students' reading interest was on level 1, which indicated that they have a low level on it. In fact, having the motivation to read is important for students (Rahman and Weda, 2018). Based on (Guthrie et al., 2000), reading motivation is the person's goals, values, and also beliefs connected to the topics, processes, and results of the reading.

It has been long known that Extensive Reading can solve such problems because Extensive Reading enables students to have more variation in their reading materials because they can read authentic texts from various sources such as newspaper, journals, tabloids, articles, books, novels, short stories, magazines and web pages and that it is actually applied outside the class room for most people consider it as joyful reading (Harmer, 2007). Research studies show that extensive reading is effective in increasing reading speed and comprehension. It appears to lead to substantial vocabulary learning and learners show their development in spelling and vocabulary knowledge. It is also reported that extensive can also improve students' affective domain such as motivation and attitude to read (Shen, 2008). (Powell, 2005) defines extensive reading as the reading of large amount of materials which are easy to understand and it is usually done in students' comfort zone outside the classroom. Hence, students are allowed to choose reading materials they want to read. If they don't find the selected reading materials interesting, they are encouraged to find other reading materials which are more suitable with their interest and level of reading comprehension.

The advancement of technology over the years has enabled students to do many activities online, including Extensive Reading activity outside the classroom. Additionally, the presence of Internet connection allows learners to gain access to an enormous amount of authentic materials to make English learning more enjoyable (Dang, 2011) There are quite many online reading platforms available on the internet such as Wattpad, Google Books, Glose, Tumblr, Goodreads, and so forth. These platforms enable their users to read extensively online (Rahman and Amir, 2019). These platforms allow its users to choose what to read based on their personal interest and preferences. These platforms, therefore, seem to get more attention popularity nowadays. For example, Wattpad claims to have an audience of more than 70 million users in 2019. Its users are free to use the platform to write and read extensively. Learners who read extensively on Wattpad are provided with massive amount 
of reading materials in various genres which they can choose based on their personal interests. Therefore, this makes Wattpad a potential platform for the students to do Extensive Reading activities outside the classroom, independently.

Wattpad was co-founded in 2006 by the two Canadian engineers and coworkers Allen Lau and Ivan Yuen as an online community of writers and readers which they claim as a platform for aspiring and experienced authors, enabling them to publish their work, get feedback and connect with other writers and readers (Ramdarshan Bold, 2018). Wattpad is therefore based on usergenerated contents and has also been described as the "YouTube for stories (without video)" (Ramdarshan Bold, 2018). Wattpad provides enormous free and paid reading materials that can support extensive reading for the students. The platform offers 21 stories genres in total that its users can select based on their own interest. The stories genres include adventure, fantasy, historical fiction, horror, humor, science fiction, non-fiction, urban, thriller, and so on. Because Wattpad is a platform that allows its users both read and write, it has writers from various countries who write stories in different languages. However, the users can select the language of the stories that they prefer. Stories written in English are enormously available for the students to read. Some popular stories that are not written in English have also been translated in English to gain more readers.

There are previous relevant studies under the same topic. However, none of the studies have explored students' perceptions towards Extensive Reading, specifically using Wattpad platform as well as the benefits the students get from doing the activity on the platform. (Arifuddin, 2018) conducted a thesis entitled "Students' Perception in the Impact of Extensive Reading Course". His study observed the students' perceptions towards an extensive reading class which was conducted in a state university in Indonesia. The findings of the study reveal that Extensive Reading approach enhances students' interest in increasing their reading. It also builds students awareness in reading either in class or beyond classroom until it turns into their habits to read more and improve their reading level. Sanubari (2018) conducted a qualitative study entitled "Students' Perception on the Online Extensive Reading". The study aimed to find out the benefits of online extensive reading which was done independently by Indonesian university students as well as its challenges. The findings of the study show that the students' perceived online extensive reading as beneficial in helping them in terms of reading activities, as well as improving students' English skill in vocabulary and grammar knowledge. (Anindita, 2020) conducted a study entitled "Efl Students' Perception Towards Extensive Reading Practices in Higher Education Level." The purpose of the study was to investigate the students' perceptions towards extensive reading subject, kinds of materials that they preferred, and its benefit to their English skills. The result of this study showed that the students have good perceptions towards extensive reading practices. Besides, extensive reading practices also enhanced students' knowledge and English skills such as writing, speaking, listening, reading, vocabulary mastery, and grammar. 
This study needs to be carried out because there have not been any studies which reveals students' perceptions towards using a big social platform like Wattpad. Students' perceptions of using the platform for extensive reading activity as well as its benefits to their language skills needs are valued and need to be discovered for the sake of the future implementation of the activity on the platform in reading classes. Based on the facts above, the researcher forms two research problems as follow;

1. What are students' perceptions towards extensive reading on Wattpad platform?

2. What are the benefits of extensive reading on Wattpad platform to students' English skills?

\section{Method}

This research is a qualitative research which employs a descriptive case study design. (Yin, 2018) defines a descriptive case study as a study which is focused and detailed. In other words, the main goal of a descriptive study is to evaluate a sample in detail and in-depth, based on an articulation of a descriptive theory. In this study, the goal set by the researcher is to describe the data, which are the students' perceptions on using Wattpad for extensive reading outside the classroom as well as its benefits to their English skills.

The participants of this study were two undergraduate students majoring English Department from a state university in Indonesia. The participants were chosen purposively for the rationale that the participants have been known, from the preliminary interview, to have used Wattpad platform for extensive reading activity outside the classroom for more than three years.

The research instrument used in this study was an in-depth interview consisting several questions related to the research problems. The interview questions were formed based on the three components of perceptions proposed by (Walgito, 2010). The researcher did an in-depth interview with the participants to gain adequate data to analyze.

The data of this study were analyzed by using interactive model proposed by (Ridder et al., 2014). Firstly, the researchers obtained the data from an indepth interview. Secondly, the researcher reduced the obtained data by deciding the main data and dumping the unimportant data. Then, the researcher presented the data in the form of word description. Finally, the researcher drew a conclusion. The researcher verified the data and made the initial conclusion to answer the research problems

\section{Findings and Discussion}

\subsection{Students perceptions' toward extensive reading on Wattpad}

Students' perceptions towards extensive reading on Wattpad are categorized and analyzed based on three components of perceptions by (Walgito, 2010) as follow;

\subsubsection{Cognitive Component}


Perception in cognitive component refers to knowledge, opinions, or beliefs of the participants toward doing extensive reading on Wattpad platform. It is obtained from the data that both two participants have positive perceptions towards extensive reading on Wattpad. In terms of knowledge, when questioned about what they know of extensive reading the participants answered;

"Extensive reading is the activity of reading for pleasure where I am free to choose what to read based on my personal interest and my level of English comprehension." (1A)

"I know extensive reading as the activity of reading for fun, usually done outside the classroom. I can choose my own reading materials based on my preferences." (1B)

Overall, both participants understand the concept of extensive reading in where extensive reading is also called reading for pleasure which is done under the principle that students must choose the reading materials by themselves based on their interests and level of comprehension. Both participants perceived similar understanding or knowledge about extensive reading activity.

Meanwhile, when asked about their knowledge and their understanding about Wattpad platform, they revealed;

"Wattpad is an online reading and writing platform which can be accessed through smartphones or personal computers. It provides me with tons of reading materials in various interesting genres." (2A)

"Wattpad is a platform where we can read and write online. It allows its users to write and read for free. It has so many various reading materials in various genres." (2B)

Both participants perceived that Wattpad is an online reading platform which provides them with enormous reading materials in various genres that they can select based on their personal interests. Thus, this makes Wattpad a potential platform for doing extensive reading outside the classroom.

When questioned about what they think of reading extensively on Wattpad, whether it is interesting or not, both participants also have similar positive perceptions. They revealed;

"Extensive reading on Wattpad has always been interesting for me as I have been doing it even before I am a university student. Wattpad has so many interesting reading materials in various genres, so I guess it supports my extensive reading activity a lot." (3A)

"I love the activity as well as the platform. I've been doing it for five years. The amounts of stories published on Wattpad is enormous and that makes it a fun place to read extensively outside the classroom." (3B)

Both participants agree that Wattpad is a good platform to do extensive reading activities because it has enormous sources of various reading materials in different genres that can support their extensive reading activities, especially reading for pleasure outside the classroom. 


\subsubsection{Affective Component}

Perception in affective component refers to the feeling or emotional aspects which are not mediated by thinking. Anchored from the data obtained from the interview. Both participants have positive perceptions towards using Wattpad as a platform to do extensive reading.

When the researcher asked a question regarding their emotional feelings when doing extensive reading on Wattpad, the participants revealed;

"I feel happy doing the activity on the platform. It's a really fun thing to do. I enjoy it so much because it makes reading less stressful. Also, I get to select what I want to read and because there are so many options of reading materials, I could just change what to read every time I find it less interesting." (4A)

"I feel like I always enjoy extensive reading on Wattpad because it is a fun thing to do. Apart from having enormous interesting reading materials in various genres, Wattpad has this feature where we can make our own library. Every time I find a good book and I don't have time to read, I can save in my library to read later. It also has this feature where writers can put music on their writings, so when I read it, I can also play the music. I like it, it's very fun." (4B).

Both participants revealed that they feel happy doing extensive reading on Wattpad. Participant A perceived extensive reading on Wattpad as a fun activity as it makes reading less stressful. Since Wattpad has numerous reading materials, it is easy for the students to change what they are reading. Whenever they do not find the reading material interesting, they could just find another one that is more suitable with their interests. Participant $B$ also perceived extensive reading on Wattpad as a fun activity. They like the feature where they can make their own library as well as the feature where they can read while playing music.

To be fair, the researcher also questioned the participants whether there are things that they do not like when doing extensive reading on Wattpad. The participants revealed;

"Overall, I love doing extensive reading on Wattpad but I sometimes found stories with similar plot and characterization even though they are written by different authors. I think it's very boring to keep reading that type of stories." (5A)

"I think... not all the reading materials on Wattpad are actually well-written. I found stories with similar plot, just with different characters' names. It is probably because the authors got inspired by another author who can publish a story which gains a lot of readers." (5B)

Apart from the positive feelings towards doing extensive reading on Wattpad perceived by the participants, both participants revealed that there are things that make the activity on the platform less enjoyable such as the similarity in plots as well as characterizations of the stories that they read, even when the stories are written by different authors.

\subsubsection{Conative Component}


Perception in conative component refers to actions or the behavior of the participants towards using Wattpad for extensive reading. According to the data gained from the in-depth interview, it is known that both participants have positive actions and behavior regarding using Wattpad for extensive reading activities.

"Nobody forced me to read on Wattpad. I discovered it myself years ago and I encouraged myself to read on the platform for my own entertainment. Later, by doing the extensive reading on Wattpad, I found out that my English skills improves unconsciously. For that reason, I think it's good for me to continue doing extensive reading on the platform." (6A)

"When I first discovered Wattpad like five years ago, I used it to read for fun only in my spare time. After some times, it turned out I enjoyed the activity a lot that it became an activity which I do regularly. I get so attached with the activity and the platform. I also think that extensive reading on Wattpad has contributed apparent improvements on my English skills unconsciously" (6B)

Both participants reveal that they discovered the platform a quite long time ago and started to encourage themselves to read extensively on the platform for entertainment. Both participants also stated that continuously doing extensive reading on Wattpad helped them improve their English skills unconsciously.

When asked about what types of reading materials they were interested in selecting for extensive reading on Wattpad, both participants answered that they mostly select fictions.

"I mostly read fiction genre because I love it attracts me the most. I like to read romantic-comedies, detectives, mystery, and so on. I am not really into non-fictions genre. I don't know why. I guess it is just not my thing." (7A)

"On Wattpad, I mostly read fiction because it is my favorite genre. Actually, my favorite genre is romance and fantasy. Oh and because I am a Harry Potter fan, sometimes I read Harry Potter fan fictions." (7B)

Participant $A$ revealed that they do not really like reading non-fictions because they are more interested in fictions such as romantic-comedies, detectives, and mystery. Meanwhile participant $B$ is also more into fiction genre even though their most favorites are romance and fantasy. Participants B also read fan fictions on Wattpad. The participants' answers in this matter is in line with the previous study conducted by (Ferrer \& Staley, 2016) and (Day \& Bamford, 2000) in where they argued that it does not matter what type of book the students are reading, as long as they enjoy it, it means that they have already executing their extensive reading practices.

\subsection{The benefits of extensive reading on Wattpad on students' English skills}

According to the students' perceptions in the above section. It is obtained from the conative component that both participants mentioned that extensive reading on Wattpad unconsciously improve their English skills. Therefore, the 
researcher further questioned both participants to what extent extensive reading on Wattpad unconsciously improve their English skills. There are some notable benefits of extensive reading on Wattpad to students' English skills mentioned by the participants as follows;

\subsubsection{Improving students' writing skills}

Both of the participants argue that extensive reading on Wattpad improve their writing skills by enhancing their knowledge of grammar and sentence structures.

"Extensive reading on Wattpad contributed a lot in enhancing my writing skills. The more I read on the platform, the more I know how a sentence is formed. I used to only understand the meaning of a sentence that I read but after a long time using Wattpad for extensive reading, it helps me a lot to know how to write a good and structurally and grammatically correct sentence just because I am used to reading sentences." - (8A)

Participant $A$ stated that after a long time doing extensive reading on Wattpad, their writing skills improve. Participant A used to only understand the meaning of a sentence, but as she spent more time doing extensive reading on Wattpad, she became used to seeing sentences. Thus, consciously, after a long time of doing extensive reading on Wattpad, she can write structurally and grammatically correct sentences.

"I think extensive reading on Wattpad really helps me to improve my writing skills. I was not actually a fan of reading before I discovered Wattpad because it was difficult for me to afford printed books written in English because they were expensive. I just started reading in English after I discovered Wattpad because most of the books are free. Firstly, when I read, I understand the meaning but when I tried to write, I failed to execute. I couldn't write because I didn't know how to write a good sentence. However, as time went by, I became more familiar with sentences structures because of the amount of times I spent on reading, especially on Wattpad. I feel like my brain just unconsciously comprehends and absorbs the knowledge that I get from the activity. Now, I am confident and I think I am able to write good sentences." - (8B)

Participant B gave similar but deeper answer regarding how extensive reading on Wattpad improved their writing skills. Participant $B$ stated that before discovering the platform, it was difficult for them read books written in English because of economical reason, so the presence of Wattpad really helped them solved that matter. When she started reading on the platform, they could understand the meaning but they were not able to write because they did not understand how to form a good sentence. As time passed by, they became more familiar with sentences and finally able to write good sentences. Participant B also argued that they unconsciously absorbed knowledge related to sentences when doing extensive reading on Wattpad.

The answers given by the participants are in line with (Renandya \& Widodo, 2016) who argued that extensive reading helps students improve their writing skill for students can adapt to the author's writing style and know how to 
write correctly. The answers given by the participants are also in line with (Park, 2016) who stated that extensive reading could contribute in improving the students' writing sub-skill such as content, organization, vocabulary language use, and mechanics.

\subsubsection{Improving students' vocabulary}

Both the participants admitted that extensive reading on Wattpad also helped them improve their vocabulary mastery. The followings are how the participants answered the question regarding how extensive reading on Wattpad improve their vocabulary.

"Of course, extensive reading on Wattpad helps me enrich my English vocabulary. When I read something new, there are always new words of which I do not even know the meaning in Bahasa Indonesia. When I find an unfamiliar word while reading on Wattpad, I don't instantly open my dictionary to find the meaning, I'll just guess their meaning based on the previous and following sentences and continue reading. After I finish reading, I usually check whether I guess the meaning of the word correctly or not. Most of the times, I could guess correctly or if it is not, it's always close to the correct meaning. I think that's how my vocabulary improves by doing extensive reading on Wattpad." (9A)

Participant $A$ believed that extensive reading on Wattpad improve their vocabulary mastery. They explained that the activity on the platform, they are always introduced to new words which they do not try to look up the dictionary to find the meaning while reading. Instead, they just guess the meaning of the unfamiliar word based on the previous and following sentences. After finishing reading, they search the word as well as its meaning to make sure that their guess is correct. They also claim that most of the times, they make correct guesses.

Meanwhile, participant $B$, apart from arguing that Wattpad enhanced their vocabulary, they further explained what types of new vocabulary that they find while reading extensively on Wattpad.

"Yeah, sure. Wattpad... I mean reading on Wattpad really helps to have better vocabulary mastery. There are always new words and phrases every time I read on the platform. I also learned slangs and idioms that the native speakers used to talk in daily conversation. I also learned figures of speech in poetries and poems." (9B)

Participant B claimed that they not only learned new words while doing extensive reading on Wattpad, but also learned phrases like slangs and idioms used by native speaker in daily conversation, as well as figures of speech in poetries and poems. As in extensive reading, the use of dictionary is restricted, the researcher further questioned participant B how they learned the meanings of all the new words and phrases that they have found and here is what they answered;

"I don't necessarily use dictionary because it will ruin the fun of reading itself, especially when I am in the most interesting part of the book. I think it does not bother me when I don't understand a word or two, I will just 
continue reading. When I finish, I usually will look it up on google and be like 'oh okay, now I know what this means. What a new knowledge'." 9B

Similar to participant A, Participant B also avoids the use of dictionary when reading extensively on Wattpad. Participant $B$ argued that the use of dictionary might ruin the fun of doing extensive reading on the platform. Unlike participant $A$, participant $B$ does not try to guess the meaning of the new words that they find. They will leave the unfamiliar words and continue reading. They will search the internet to help them find the meanings of the words after they finish reading.

From the participants' answers, it can be concluded that they have done extensive reading on the platform under the principles proposed by The Extensive Reading Foundation's Guide to Extensive Reading (2011) in (Uden, 2013) that explained when students read extensively, they read quickly, enjoyably, have adequate comprehension, so they do not necessarily use a dictionary.

These responses shown by the participants are also in line with (McLean \& Rouault, 2017) who found that extensive reading could construct reading fluency, improve vocabulary knowledge, increase students' motivation to read, and help to sharpen the use of reading strategy. Participants' answers are also relevant with the study conducted by Sanubari (2018) which found out that online extensive reading can improve students' vocabulary mastery.

\subsubsection{Improving students' speaking skills}

Both participants also admitted that extensive reading on Wattpad gave contribution in improving their speaking skills. The followings are how the participants answered the question regarding how extensive reading on Wattpad improve their speaking skills.

"Yeah, I think extensive reading on Wattpad also helped me improve my skills in speaking. The more I read on the platform, the more I become familiar with words, phrases, sentence structures and other stuffs. It helps me easier to think in English and produce spoken and written sentences in English too. I practice speaking with my peers." (10A)

"Obviously, extensive reading on Wattpad contributes to my speaking skills. As my understanding of grammar improves as well as my vocabulary mastery, it is easier for me to speak English. However, the activity on the platform does not give significant contribution to my pronunciation because I am used to seeing written forms of sentences, sometimes I have no idea how a word is pronounced and I normally don't really care about it until somebody corrects me. I practice speaking by having a conversation with myself." (10B)

Both participants claimed as extensive reading on Wattpad improves their grammar knowledge as well as vocabulary mastery, it also improves their speaking skills. Participant A claimed that the activity on the platform helped them improve their skill to think and produced spoken and written sentences in English. Participant B answered similarly, however, they also stated that the activity on the platform does not significantly improve their pronunciation 
because they are used to seeing written forms of sentences. Sometimes, when doing extensive reading on Wattpad, they do not understand how a word is pronounced which they do not concern much until they are corrected by somebody. Overall, these answers of the participants are in line with a previous study conducted by (Jain, 2013) who argued that by practicing and performing the words, students can improve their speaking skill.

\subsubsection{Improving students' listening skills}

Both participants also claimed that their listening skills improved from doing extensive reading on Wattpad.

"Yeah, I think extensive reading on Wattpad also improve my listening skills unconsciously. Since I started reading on the platform, I have become more aware of how native speakers talk to each other from the dialogues that I read. As I mentioned previously, reading on Wattpad also developed my vocabulary mastery that I am now familiar with words and how they are pronounced. When I practice listening by listening to a podcast or something, I can listen to it with closed eyes, not struggling to read the subtitles, just because I mostly understand what the speaker is saying." (11A)

Participant A believed that since they started doing extensive reading on Wattpad, they became more aware of how the language style used by native speakers to talk to each other through the dialogues that she has read. Participant $A$ further explained that as their vocabulary mastery developed and she has become familiar with words and how they are pronounced, it makes her easier to practice listening as she generally understands what the speaker is saying.

"I think extensive reading on Wattpad helped me improve my listening skills, but not very significantly. It's because I read written words rather than listen to spoken words, sometimes I do not understand how to a word is pronounced correctly. I mean sometimes I'm very familiar with a word but I don't really know its correct pronunciation that when a native speaker says that word in a movie or something, it takes me a while to realize 'Oh, it's that word?' Do you know what I mean?" - (11B)

Meanwhile, participant $B$ argued that extensive reading on Wattpad helped them improve their listening skills, but not very significantly. They argued it is because their activity is reading rather than listening. There are times when they are familiar with a word but do not know the actual pronunciation, so when a native speaker says that word, it will take a while for the participant to realize that they have actually known the word before.

However, both of the participants agree that extensive reading on Wattpad give contributions to their listening skills which is in line by (Renandya \& Widodo, 2016) that stated that extensive reading has a positive effect on listening fluency and vocabulary development.

Both the participants admitted that extensive reading on Wattpad also helped them improve their vocabulary mastery. The followings are how the 
participants answered the question regarding how extensive reading on Wattpad improve their vocabulary.

Participant $A$ revealed that they do not really like reading non-fictions because they are more interested in fictions such as romantic-comedies, detectives, and mystery. Meanwhile participant $B$ is also more into fiction genre even though their most favorites are romance and fantasy. Participants B also read fan fictions on Wattpad. The participants' answers in this matter is in line with the previous study conducted by (Ferrer \& Staley, 2016) and (Day \& Bamford, 2000) in where they argued that it does not matter what type of book the students are reading, as long as they enjoy it, it means that they have already executing their extensive reading practices.

\section{Conclusion}

In conclusion, this study presents students' positive perceptions towards extensive reading on Wattpad. The perceptions of the students were categorized into three elements namely cognitive, affective, and conative component. In cognitive component, the students perceived extensive reading on Wattpad is a fun and enjoyable activity as Wattpad provides them enormous reading materials in various genres that they can select based on their personal interests. In affective component, the students feel happy doing the activity on the platform with all the features it provides. In conative component, the students revealed that they discovered the platform and encouraged themselves to use it for extensive reading activity. It is also shown that the students prefer fictional books rather then non-fictional ones. Looking deeper towards their perceptions towards extensive reading on Wattpad, the students also agree that the activity on the platform helped them improve their English skills in general. There are four notable contributions of extensive reading on Wattpad that the students mentioned. The students agree that extensive reading on Wattpad could help them unconsciously improve their writing skills, vocabulary mastery, speaking skills, as well as listening skills.

\section{References}

Andreas, S. (2018). PISA 2018 Insights and Interpretations. OECD Publishing.

Anindita, C. (2020). EFL Students' Perception towards Extensive Reading Practices in Higher Educatuion Level. Retain.

Arifuddin, A. (2018). Students' Perception in the Impact of Extensive REading Course.

Cain, K., Oakhill, J., \& Bryant, P. (2004). Children's Reading Comprehension Ability: Concurrent Prediction by Working Memory, Verbal Ability, and Component Skills. Journal of Educational Psychology. https://doi.org/10.1037/0022-0663.96.1.31

Dang, X. (2011). Factors Influencing Teachers' Use of ICT in Language Teaching: A Case Study of Hanoi University, Vietnam. International Conference "ICT for Language Learning."

Day, R., \& Bamford, J. (2000). Reaching Reluctant Readers. The Forum. 
Ferrer, E., \& Staley, K. (2016). Designing an EFL Reading Program to Promote Literacy Skills, Critical Thinking, and Creativity. CATESOL Journal.

Grabe, W. (2009). Reading in a Second Language Moving from Theory to Practice. Reading in a Second Language: Moving from Theory to Practice.

Guthrie, J. T., Wigfield, A., \& VonSecker, C. (2000). Effects of integrated instruction on motivation and strategy use in reading. Journal of Educational Psychology. https://doi.org/10.1037/0022-0663.92.2.331

Hacker, D. J. (2009). Handbook of Metacognition in Education. In Handbook of Metacognition in Education. https://doi.org/10.4324/9780203876428

Harmer, J. (2007). The Practice of English Language Teaching Fourth Edition. Cambridge: Pearson Longman.

Harrison, C. (2004). Understanding Reading Development. In Understanding Reading Development. https://doi.org/10.4135/9781446215401

Jain, S. (2013). Advantages of Podcasts in English Language. Journal of Indian Research.

Mason, B., \& Krashen, S. (1997). Extensive Reading in English as a Foreign Language. System. https://doi.org/10.1016/S0346-251X(96)00063-2

McLean, S., \& Rouault, G. (2017). The Effectiveness and Efficiency of Extensive Reading at Developing Reading Rates. System. https://doi.org/10.1016/j.system.2017.09.003

Mokhtari, K., Reichard, C. A., \& Gardner, A. (2009). The Impact of Internet and Television Use on the Reading Habits and Practices of College Students. Journal of Adolescent \& Adult Literacy. https://doi.org/10.1598/jaal.52.7.6

Park, J. (2016). Integrating Reading and Writing through Extensive Reading. ELT Journal. https://doi.org/10.1093/elt/ccv049

Powell, S. (2005). Extensive Reading and its Role in Japanese High Schools. The Reading Matrix.

Ramdarshan, B. M. (2018). The Return of the Social Author: Negotiating Authority and Influence on Wattpad. Convergence. https://doi.org/10.1177/1354856516654459

Rahman, F. (2018). The Constraints of Foreign Learners in Reading English Literary Works: A Case Study at Hasanuddin University. Journal of Arts and Humanities, 7(2), 01. https://doi.org/10.18533/journal.v7i2.1327

Rahman, F., \& Amir, P. (2019). Trends in Reading Literary Fiction in Print and Cyber Media by Undergraduate Students of Hasanuddin University. International Journal of Education and Practice, 7(2), 66-77.

Renandya, W. A., \& Widodo, H. P. (2016). English Language Teaching Today: An Introduction. https://doi.org/10.1007/978-3-319-38834-2_1

Ridder, H. G., Miles, M. B., Michael Huberman, A., \& Saldaña, J. (2014). Qualitative data analysis. A methods sourcebook. Zeitschrift Fur Personalforschung. https://doi.org/10.1177/239700221402800402 
Shen, M. (2008). EFL Learners' Responses to Extensive Reading: Survey and Pedagogical Applications. The Reading Matrix.

Uden, J. (2013). The Extensive Reading Foundation's Guide to Extensive Reading. ELT Journal. https://doi.org/10.1093/elt/cct010

Walgito, B. (2010). Pengantar Psikologi Sosial. Yogyakarta: Andi Ofset.

Rahman, F., \& Weda, S. (2018). Students' perceptions in appreciating English literary works through critical comment: A case study at Hasanuddin University and Universitas Negeri Makassar. Asian EFL Journal, 20(3), 149-172.

Yin, R. K. (2018). Case Study Research and Applications. In Case Study Research and Applications: Design and Methods. 